Bartosz Wysocki

Uniwersytet Gdański

\title{
Prawo do bycia zapomnianym - prawem cyfrowej rzeczywistości
}

Internet jest narzędziem komunikacji gromadzącym niezliczoną liczbę informacji, które nigdy nie znikają z jego przestrzeni. Dotyczy to też informacji dezaktualizujących się z biegiem czasu. W kontekście podstawowych praw jednostki - takich jak ochrona danych osobowych - jest to kwestia o zasadniczym znaczeniu. Jak dostosować prawo do technologicznej zmiany?

Z problemem ochrony danych osobowych $w$ dobie rozwoju społeczeństwa informacyjnego musi sobie poradzić nie tylko europejski prawodawca. Informacja raz umieszczona w sieci przestaje podlegać podmiotowi, który ją tam umieścił. Wynika to $\mathrm{z}$ charakteru technologicznego internetu jako sieci autonomicznie połączonych komputerów stanowiących węzły działające niezależnie. Zwraca na to uwagę rzecznik generalny w opinii dotyczącej sprawy C-131/12 Google Spain i Google przeciwko Agencia Española de Protección de Datos (AEPD). W sprawie tej zostały skierowane pytania prejudycjalne do Trybunału Sprawiedliwości w związku ze sporem pomiędzy Google i Google Spain a hiszpańskim organem ochrony danych (AEPD) i obywatelem hiszpańskim. Spór dotyczył obowiązku podjęcia przez Google Spain i Google środków niezbędnych do usunięcia danych osobowych z indeksów wyszukiwania i uniemożliwienia dostępu do tych danych w przyszłości. Sprawa dotyczyła informacji zamieszczonej w 1998 roku w poczytnym hiszpańskim dzienniku na temat zajęcia nieruchomości, wynikającego z niespłaconych należności na rzecz zakładu ubezpieczeń społecznych. Osoba, której dane dotyczą, wymieniona była jako właściciel. W późniejszym terminie wydawca udostępnił wersję gazety $\mathrm{w}$ internecie. Po jedenastu latach osoba ta skontaktowała się z wydawcą gazety, twierdząc, że po wpisaniu swojego imienia i nazwiska w wyszukiwarkę Google ukazuje się odwołanie do stron gazety z ogłoszeniem dotyczącym licytacji nieruchomości. Poszkodowany utrzymywał, że nakaz zajęcia był już rozstrzygnięty i rozwiązany od lat, niemniej jednak ogłoszenie cały czas pojawiało się w wynikach wyszukiwania. Wydawca, ustosunkowując się do wniosku, stwierdzil, że usunięcie danych nie jest właściwe, ponieważ publikację zrealizowano na podstawie obowiązujących przepisów prawa. Osoba poszkodowana zwróciła się do Google Spain z prośbą, aby wyniki wyszukiwania po wpisaniu imienia i nazwiska nie wskazywały linków do gazety z ogłoszeniem. Wniosek został przekazany do Google Inc. $z$ siedzibą w Kalifornii, gdzie świadczy się usługę wyszukiwania w internecie. 
Następnie poszkodowany zwrócił się do AEPD, aby zobowiązał wydawcę do usunięcia danych osobowych lub zmiany publikacji tak, żeby nie pojawiały się dane osobowe. Domagał się również zobowiązania Google do usunięcia lub ukrycia jego danych osobowych, aby nie wiązały się z ogłoszeniem licytacji. Hiszpański Urząd Ochrony Danych Osobowych przyjął skargę od poszkodowanego i zażądał od Google Spain SL oraz Google Inc. wycofania danych skarżącego ze swoich indeksów (list). Uznał jednak, że informacja o licytacji opublikowana w gazecie musi pozostać ze względu na swoje uzasadnienie prawne. Google Spain i Google Inc. wniosły dwa odwołania od tej decyzji, żądając jej uchylenia ${ }^{1}$.

Sędziowie zebrali w dziewięciu pytaniach ${ }^{2}$ wszystkie wątpliwości prawne, z którymi się zetknęli, rozpatrując ten przypadek. Sąd rozumie, że skarga dotyczy problemu zobowiązań obsługujących wyszukiwarki internetowe w zakresie ochrony danych osobowych. Zainteresowane osoby mogą nie życzyć sobie, aby określone informacje publikowane na stronach internetowych podmiotów trzecich, zawierające ich dane personalne i pozwalające na ich identyfikowanie, były umieszczane, indeksowane i udostępniane do dyspozycji internautów w nieskończoność.

Pierwsza wątpliwość, jaką powzięli sędziowie, dotyczy terytorialnego stosowania przepisów wspólnotowych i krajowych w zakresie ochrony danych osobowych. Czy mają one zastosowanie w tym przypadku, czy - tak jak utrzymuje Google poszkodowani powinni zwracać się do sądów stanu Kalifornia, gdzie znajduje się siedziba spółki matki grupy?

Sąd pyta także, czy wyszukiwarki podczas indeksowania informacji dokonują przetwarzania danych osobowych, czy są odpowiedzialne za ich przetwarzanie i powinny z tego względu przestrzegać prawa do usunięcia danych i/lub sprzeciwu bezpośrednio zainteresowanego, choć informacja zostaje zachowana w źródłach oryginalnych, ponieważ uznano ją za legalną.

Wreszcie sędziowie pytają Trybunał Sprawiedliwości Unii Europejskiej (TSUE), czy ochrona danych osobowych dotyczy sytuacji, gdy zainteresowany sprzeciwia się indeksowaniu i rozprzestrzenianiu informacji jego dotyczącej, chociaż jest ona legalna i precyzyjna u swego źródła, gdyż uznaje ją za negatywną lub szkodliwą dla swojej osoby (Europa Praw Człowieka 2012).

\section{Cecha charakterystyczna internetu}

Wszelka treść, w tym dane osobowe, czy to w formie tekstów, czy też materiałów audiowizualnych mogą być natychmiast i stale dostępne w formacie cyfrowym na całym świecie. Internet zrewolucjonizował nasze życie poprzez usunięcie barier

1 Opinia rzecznika generalnego Nilia Jaasinena przedstawiona w dniu 25.06.2013, sprawa C-131/12, http://curia.europa.eu/juris/document/document.jsf?text $=\&$ docid $=138782 \&$ pageIndex $=0 \&$ doclang $=$ PL\&mode $=$ req\&dir $=\& o c c=$ first\&part $=1 \& c i d=305413$ [dostęp: 23.11 .2015 ].

2 Wniosek o wydanie orzeczenia w trybie prejudycjalnym złożony przez Audiencia Nacional (Hiszpania) w dniu 9 marca 2012 r. - Google Spain, S.L., Google, Inc. przeciwko Agencia de Protección de Datos (AEPD), Mario Costeja González (Sprawa C-131/12), http://curia.europa.eu/juris/document/ document.jsf?docid=123131\&doclang $=$ PL [dostęp: 23.11.2015]. 
technicznych i instytucjonalnych w rozpowszechnieniu i odbiorze informacji ${ }^{3}$. Informacja powinna być wolna ${ }^{4}$, ogólnodostępna, a wszystko, co stoi na drodze jej wolności, musi być pomijane. Do takich przeszkód należy władza, biurokracja oraz dyskryminacja.

Tego typu rozumienie wolności informacji stanowi wyzwanie dla prawodawstwa. Podmiot umieszczający informację w internecie traci nad nią kontrolę. Autonomia informacji jest cechą konstytutywną internetu. Zależność pomiędzy nią i autorem jest niwelowana. Komunikat w swojej autonomiczności rozprzestrzenia się niezależnie od intencji osoby, która go zamieściła. Niemożliwe jest utrzymanie kontroli nad niezależną, pozbawioną hierarchii siecią. Kontrola jest skuteczna, kiedy struktura ma silne cechy hierarchiczne. Jeśli struktura jest pozbawiona hierarchii, kontrola jest ograniczona lub wręcz niemożliwa. Sprawa nr C-131/12 jest symptomatyczna dla społeczeństwa informacyjnego. Wynika to z dwóch zasadniczych przesłanek. Pierwsza dotyczy ochrony danych osobowych, które są gwarantowane przez prawo europejskie. Druga z przesłanek dotyczy wolności prowadzania działalności gospodarczej. Dochodzi do sytuacji, gdzie ścierają się dwie równoważne wartości.

W przypadku internetu należy rozróżnić trzy sytuacje odnoszące się do danych osobowych:

- pierwsza dotyczy opublikowania danych osobowych na jakiejkolwiek stronie internetowej;

- w drugiej wyszukiwarka internetowa wskazuje wyniki wyszukiwania kierujące użytkownika internetu do źródłowej strony internetowej;

- w trzeciej sytuacji użytkownik dokonuje przeszukiwania za pomocą wyszukiwarki internetowej, a niektóre z jego danych osobowych, na przykład adres IP, zostają przeniesione do dostawcy usług wyszukiwania 5 .

Ustosunkowanie się prawodawstwa i orzecznictwa w poruszanych trzech kwestiach ma kluczowe znaczenie dla rozstrzygnięcia zasad funkcjonowania jednego z podstawowych narzędzi społeczeństwa internetowego jakim jest wyszukiwarka. Sprawa Google przeciwko AEPD i Mario Costeja Gonzàlezowi jest bezprecedensowa. Jest pierwszą sprawą wniesioną do Trybunału Sprawiedliwości, gdzie zwrócono się o wykładnię dyrektyw w sprawie ochrony danych osobowych w kontekście

\footnotetext{
${ }^{3}$ Opinia rzecznika generalnego Nilia Jaasinena przedstawiona w dniu 25.06.2013...

${ }^{4}$ Wolność jest rozumiana jako niczym nieskrępowany dostęp, brak barier instytucjonalnych i technicznych, które ograniczają informacje. „W same prawa optyki wpisana jest deformacja. Obiektyw zawsze dokonuje selekcji, pokazuje jakiś wycinek rzeczywistości, który poprzez mechanizm powiększenia zyskuje walory obrazu całościowego. Widz jest przekonany, że cały tamten świat tak wygląda. Jest to przykład, że w świecie pełnym informacji można jednocześnie uprawiać pełną dezinformację" (Wang 2001: 11). „Z jednej strony informacja chce być droga bo jest wyjątkowo cenna. Odpowiednia informacja $\mathrm{w}$ odpowiednim miejscu zmienia jakość życia. Ale z drugiej strony informacja chce być darmowa, bo koszty jej wydobycia stale się zmniejszą. To są dwie walczące ze sobą tendencje" (Anderson 2011: 103). W cytacie Andersona jest istotne uchwycenie ekonomicznego związku pomiędzy światem idei a technologią. Nadanie informacji antropomorficznej metafory, która sugeruje, że informacji przypisuje się pragnienie, a nie polityczną postawę (informacja „chce być”, a nie „powinna być"), sugeruje wolność informacji charakterystyczną siłą natury (zob. Anderson 2011: 102-103).

${ }^{5}$ Opinia rzecznika generalnego Nilia Jaasinena przedstawiona w dniu 25.06.2013...
} 
wyszukiwarek internetowych. Z prawnego punktu widzenia po wprowadzeniu nowych technologii, które przekraczają granice, limity czasowe i które rozwinęly się po uchwaleniu obecnych regulacji, jest wymagana nowa wykładania przepisów o ochronie danych osobowych. Tylko jaka?

\section{Stanowiska i opinie $\mathrm{w}$ trakcie postepowania}

Rzecznik generalny poszukuje odpowiedzi na to pytanie, ważąc prawa zagwarantowane przez Kartę Praw Podstawowych. Na jednej szali kładzie prawo do poszanowania życia prywatnego i rodzinnego, którego elementem jest prawo do ochrony danych osobowych. Na drugiej - wolność wypowiedzi wydawców stron internetowych i osób publikujących w internecie oraz prawo do informacji użytkowników internetu, które w świetle rosnącej tendencji reżimów autorytarnych do cenzurowania treści zasługuje - zdaniem rzecznika - na szczególną ochronę w prawie UE. Dokłada do tego prawo do prowadzenia działalności gospodarczej dostawców usług wyszukiwania (Europa Praw Człowieka 2013).

Wyszukiwarka jest jednym z podstawowych narzędzi wykorzystywanych $\mathrm{w}$ internecie. Jej popularność wymusza refleksje nad funkcjonowaniem tego narzędzia w kontekście prawnej ochrony dóbr osobistych. Taka refleksja jest potrzebna, aby zapewnić jednostkom funkcjonującym w przestrzeni cyfrowej dostęp do swoich danych i możliwość modyfikowania ich na bieżąco oraz ich usunięcia. Takie rozwiązanie ma zapewnić propozycja przepisów przedstawiona przez Komisję Europejską (European Commission 2012b). Dnia 25 stycznia 2012 roku Komisja Europejska przedstawiła projekt reformy unijnych przepisów o ochronie danych, które przyjęto w 1995 roku. Zaproponowane zmiany mają wzmocnić prawo do prywatności $w$ internecie między innymi za sprawą zobowiązania wszystkich, którzy oferują usługi w sieci, do bardziej przejrzystego zarządzania danymi. Zgodnie z nowym projektem dane można usunąć i przestać je rozpowszechniać, gdy zaistnieje jedna z przesłanek:

- dane nie są już potrzebne do celów, do których były zebrane;

- podmiot danych odwołuje zgodę, na której opiera się przetwarzanie danych, lub minął okres ich przechowywania, na który wyrażono zgodę, oraz jeśli nie ma już podstawy prawnej przetwarzania danych;

- podmiot danych sprzeciwia się przetwarzaniu danych osobowych;

- przetwarzanie danych nie jest zgodne z rozporządzeniem (European Commission 2012a).

Nowelizacja ustawy o ochronie danych osobowych uwzględnia zmianę technologiczną, która zaszła w społeczeństwie, oraz możliwości, jakie daje w dostępie do danych osobowych. Część państw członkowskich krytycznie odnosi się do projektu Komisji Europejskiej. Jako argument wskazuje, że zaproponowane rozwiązania będą zbyt dużym obciążeniem dla przedsiębiorców.

Również Europejska Agencja ds. Bezpieczeństwa Sieci i Informacji (The European Network and Information Security Agency - ENISA) wskazuje w raporcie, że 
przeszkody natury technicznej mogą niekorzystnie wpłynąć na prawne rozwiązania zaproponowane przez Komisję Europejską w kwestii prawa do bycia zapomnianym (ang. right to be forgotten), szczególnie, gdy dotyczy to dużych danych.

Dla każdej z rozsądnych interpretacji prawa do bycia zapomnianym, czysto techniczne i kompleksowe rozwiązanie w celu egzekwowania prawa w internecie jest zwyczajnie niemożliwe. Konieczne jest podejście interdyscyplinarne, a decydenci powinni być świadomi tego faktu. Warto zastanowić się nad tym, jak agregowane i pochodne formy informacji (na przykład statystyki) będą się zachowywać po użyciu prawa do bycia zapomnianym na surowych danych, z których korzysta się w ich tworzeniu. Usuwanie zapomnianych informacji ze wszystkich form może stanowić poważne wyzwanie techniczne (Druschel, Backes, Tirtea 2011: 2) .

Usunięcie obrazów i postów widocznych publicznie jest w zasadzie bez problemowe. Sytuacja komplikuje się, kiedy mamy do czynienia z dużymi danymi, na przykład gdy informacje, które chcemy usunąć, zostały przeanalizowane i jest potrzebny stały wgląd w te dane.

Według ENISA głównym problemem rozporządzenia jest zbyt szerokie ujęcie. Rozporządzenie nie określa na przykład, kto ma prawo do bycia zapomnianym, i jakich informacji ma ono dotyczyć. Wskazano również na niejasność definicji danych osobowych, opisując je jako informacje, które mogą być jednoznacznie połączone z możliwością identyfikacji osoby fizycznej. Definicja, która jest niezbędna do tego, aby skutecznie egzekwować prawo do bycia zapomnianym, jest zbyt niejasna.

Rozporządzenie zostawia do interpretacji fakt, czy dane zawierają informacje, które mogą być używane do identyfikacji osoby z dużym prawdopodobieństwem, ale nie z pewnością, np. zdjęcie osoby lub konto danej osoby w jej historii czy jej aktywna działalność. Nie jest też jasne, czy definicja zawiera informacje identyfikujące osobę nie jednoznacznie, ale jako członka mniej lub bardziej większego zbioru jednostek takich, jak na przykład rodzina (Druschel, Backes, Tirtea 2011: 6).

Według krytyków proponowane zmiany zostały sformułowane zbyt szeroko. Może to spowodować nieproporcjonalne obciążenie administratorów danych. Takie stanowisko zajął Europejski Inspektor Danych Osobowych (EDPS), który pozytywnie oceniając propozycje wprowadzenia prawa do bycia zapomnianym, jednocześnie zauważa konieczność sprecyzowania jego zakresu (Hustinx 2012). EDPS przyznaje, że zaproponowane zmiany zawierają bardziej realistyczne zobowiązania starannego działania, a nie zobowiązania rezultatu. Ponadto zdaniem EDPS sugerowane rozwiązanie nakłada na administratorów obowiązek informowania o zmianie, poprawieniu lub usunięciu danych każdego odbiorcę, któremu te dane ujawniono. Wyjątkiem jest sytuacja, kiedy taka informacja będzie niemożliwa lub będzie wymagać niewspółmiernego wysiłku. W artykule podkreślono więc, że od administratorów danych osobowych nie będzie oczekiwać się niemożliwego. Według EDPS w celu zapewnienia efektywności prawa do bycia zapomnianym, projekt rozporządzenia potrzebuje konkretyzacji. Nieostre sformułowania „wszelki

${ }^{6}$ Tłumaczenia - B.W., jeśli nie zaznaczono inaczej. 
uzasadnione kroki" podlegać będzie dalszej interpretacji, która może określić zakres tego prawa.

Interesujące jest stanowisko polskiego rządu w tej sprawie. Jak celnie zauważa Piotr Waglowski (2012), w jej kontekście ujawnia się inna cecha konstytutywna społeczeństwa informacyjnego - dostęp do informacji publicznej. W tej konkretnej sprawie dopiero pod naciskiem organizacji pozarządowej możliwe było poznanie stanowiska rządu polskiego w kluczowym dla społeczeństwa informacyjnego aspekcie. W odniesieniu do głównego pytania dotyczącego prawa do bycia zapomnianym oraz obowiązku nakładanego na wyszukiwarki rząd polski nie zajął jednoznacznego stanowiska. Na wstępie zdefiniowano wyszukiwarkę jako „program lub strona internetowa, której zadaniem jest ułatwienie użytkownikom znalezienia informacji. Przetwarza ona różne dane, w tym dane osobowe użytkowników sieci" (Majczyna, Szpunar 2012). Rząd wyraża pogląd, że funkcjonowanie wyszukiwarek polegające na zlokalizowaniu informacji opublikowanych lub zamieszczonych w sieci przez osoby trzecie, indeksowaniu ich w sposób automatyczny, czasowym przechowywaniu takich informacji i wreszcie ich udostępnianiu internautom w sposób uporządkowany zgodnie z określonymi preferencjami, w sytuacji gdy takie informacje zawierają dane osobowe osób trzecich, jest przetwarzaniem danych w rozumieniu art. 2 lit. b) dyrektywy 95/46/WE.

\section{Wątpliwości natury prawnej i społecznej}

Kazus hiszpański wykazał szereg wątpliwości w obszarze ochrony danych osobowych i prawa do bycia zapomnianym. Wątpliwości te w dużej mierze dotyczą działania wyszukiwarek internetowych, między innymi zbierania danych o użytkowniku i polityki prywatności. Kontrowersje budzi czas przechowywania danych i możliwości powiązania ich z tożsamością osoby. Innym problemem jest podstawowa funkcja wyszukiwarki, czyli dostarczanie listy wyszukiwania. Funkcja ta budzi poważne zastrzeżenia w kontekście prawa do bycia zapomnianym. Temat jest o tyle dyskusyjny, że aby móc spełniać swoje podstawowe zdanie, wyszukiwarki muszą indeksować strony internetowe. W praktyce oznacza to kopiowanie zawartości stron internetowych przez specjalne aplikacje w celu ułatwienia użytkownikowi odnalezienia wyszukiwanych treści. W kontekście dyskusji na temat praktycznych konsekwencji obowiązywania prawa do bycia zapomnianym nasuwa się pytanie, czy można żądać usunięcia z wyników wyszukiwania, które pokazują się po wpisaniu imienia i nazwiska, odnośników do niepochlebnych czy też nieaktualnych informacji (Smętek, Warso 2012).

W omawianym przypadku jest jeszcze jedna kwestia, którą warto przeanalizować. Dotyczy istotnych informacji, szczególnie tych newralgicznych, które po pewnym czasie powinny być niedostępne. W prawie karnym istnieje instytucja zatarcia skazania, której znaczenie przypomina Michał Ilnicki: „[...] jak słusznie wskazano w doktrynie zatarcie skazania jest instytucją, która ma na celu usunięcie jego konsekwencji prawnych i społecznych, ułatwiając w ten sposób normalne życie 
skazanego, który przez wymagany prawem okres przestrzegł porządku prawnego" (Ilnicki 2014: 135). Kiedy rozproszona po internecie informacja zaczyna - używając kolokwialnego języka - niemal żyć własnym życiem, instytucja zatarcia skazania ma ograniczone możliwości działania. Nie ma jednej osoby, instytucji odpowiedzialnej za nadzór na informacją. W opisywanym przypadku nie jest to (do czasu wydania wyroku przez Trybunał Sprawiedliwości) ani gazeta, która zamieściła informacje zgodne z prawdą, ani wyszukiwarka. Zmienił się model dystrybucji informacji. Konsekwencją rozwoju technologicznego jest zmiana pojęcia czasu, który przestał mieć wymiar linearny. Możemy sobie wyobrazić tę sytuację w rzeczywistości przedinternetowej. Gazeta publikuje informację o licytacji. Informacja ta jest tak długo dostępna, jak długo w sprzedaży pozostaje nakład tej gazety - możemy przyjąć, że jest on ograniczony. Następnie informacja trafia do archiwum, gdzie docierają do niej tylko osoby zainteresowane. Informacja w internecie jest dostępna cały czas, trudno ją zlokalizować, a tym samym usunąć czy zablokować. Dlatego jej żywotność powoduje wywoływanie różnych skutków odsuniętych w czasie. Informacja odnosząca się kiedyś do rzeczywistości w przyszłości może być wykorzystana przeciwko osobie, której dotyczyła. Ilnicki stosuje kategorie „postzniesławienia” dla opisania tego zjawiska.

Takie bowiem „postzniesławienie" przyjmę dla informacji, które w chwili publikacji nie może być obiektywnie poczytane jako zniesławiająca. Jednakże w związku z obowiązywaniem tej informacji w czasie powoduje ona nadmierną stygmatyzacje podmiotu tej informacji (Ilnicki 2014: 135).

Przykładem postzniesławienia jest hiszpański kazus. Ochrona dóbr osobistych jest kumulatywna, ponieważ zapewniają je europejskie przepisy prawa - jak chociażby Karta Praw Podstawowych - zaś na gruncie polskim Konstytucja art. 47, kodeks karny art. 212, gdzie jest mowa o zniesławieniu (Ilnicki 2014: 136). Dlatego ochrona dóbr osobistych powinna być gwarantowana bez względu na technologiczne możliwości społeczeństwa. W ślad za rozwojem technologii powinna iść taka działalność prawodawcza, która skutecznie zapewni ochronę podstawowych praw.

Wymazywanie pamięci ma spore konsekwencje społeczne. Z jednej strony przeraża nas to, jak internet „nie zapomina”, z drugiej jednak strony nie uświadamiamy sobie czasami kruchości cyfrowych informacji. Pamięć cyfrowa istnieje tak długo, jak jesteśmy w stanie odczytać zgromadzone w niej informacje. Już dziś trudnością byłoby odczytanie informacji zapisanych na dyskietce, chociażby ze względu na problem ze znalezieniem odpowiedniego sprzętu czy oprogramowania umożliwiającego odczytanie danych. Ufni technologii, powierzamy swoje dane firmom świadczącym usługi w chmurze, licząc na to, że tam będą wiecznie przechowywane i bezpiecznie (Moglen 2013: 129).

Sprawa wyroku jest szersza niż tyko dyskusja na temat wolności słowa i możliwości oddziaływania na cyfrową rzeczywistość. Dotyczy również istotnych społecznie i kulturowo norm regulujących kwestie pamięci jako ważnego elementu zbiorowej i indywidualnej tożsamości oraz prawa do zapomnienia i przebaczania. 


\section{Treść wyroku}

Wszystkie wyżej wymienione wątpliwości i sugestie nie mają znaczenia w obliczu wyroku Trybunału Sprawiedliwości. Czego właściwie dotyczy, i jak należy go interpretować?

Trybunał Sprawiedliwości stwierdził, że operator wyszukiwarki internetowej nie tylko przetwarza dane osobowe, ale jest też ich administratorem - to jest podmiotem, który określa cele i środki przetwarzania danych. W związku z tym jest on zobowiązany do spełnienia wymogów, które nakładają na administratorów danych przepisy dyrektywy 95/46/WE. Ponadto doszedł do wniosku, że Google Inc., choć jest spółką prawa amerykańskiego, podlega przepisom prawa unijnego, gdyż Google Spain, jego spółka zależna, prowadzi na terytorium hiszpańskim działalność gospodarczą.

Co tak naprawdę nakazał firmie Google TSUE? Na czym konkretnie ma polegać „znikanie z wyszukiwarki"? Co w tym nowego i czym to grozi?

Wcale nie to, że każdy ma prawo wymazać swoją historię z wyszukiwarki. Sąd nie nakazał też usuwania danych $\mathrm{z}$ internetu. Prawo do zapomnienia $\mathrm{w}$ wersji zaproponowanej przez TSUE sprowadza się do możliwości skorygowania sposobu, $\mathrm{w}$ jaki wyszukiwarka łączy dane osobowe zawarte w pytaniu z odpowiedzią. Jeśli więc udowodnimy, że konkretna informacja nie powinna być łączona z naszym imieniem i nazwiskiem (bo jest nieprawdziwa, nieaktualna albo nie ma już interesu publicznego w jej publikacji), wyszukiwarka powinna zmienić sposób jej indeksowania i nie wyświetlać więcej tego wyniku w odpowiedzi na pytanie zawierające nasze dane osobowe. Taka ingerencja nie wpływa na dostępność samej informacji: nadal będzie można do niej dotrzeć, zadając wyszukiwarce inne pytanie czy po prostu wchodząc na stronę, gdzie została opublikowana (Szymielewicz 2014).

TSUE dostrzegł jednak, że użytkownicy internetu mogą mieć uzasadniony interes w uzyskaniu dostępu do informacji, w związku z czym należy dążyć do znalezienia punktu równowagi pomiędzy tym interesem a prawami podstawowymi osoby, której dotyczą dane. Chodzi w szczególności o jej prawa do poszanowania życia prywatnego i ochrony danych osobowych. Trybunał jednoznacznie stwierdzil, że prawa osoby, której dotyczą dane, są co do zasady nadrzędne wobec tego interesu internautów.

Zdzisław Brodecki w Światyni wo cyberkulturze: technologie cyfrowe i prawo w spoteczeństwie wiedzy napisał:

U progu XXI wieku obserwujemy w życiu publicznym dwa spory o podstawowym znaczeniu dla filozofii prawa, które nakładają się na siebie: spór między "atomistami” a "holistami” i spór między „,indywidualizmem” a "kolektywizmem”. Zazwyczaj „atomiści” "opowiadają" się za indywidualizmem i są liberałami, a holiści preferują kolektywizm i są komunitarianami. Jest to myśl Zachodu, którą należy skonfrontować z filozofią Wschodu. Tylko w ten sposób można rozpocząć budowę pomostu myślowego w celu przezwyciężenia kryzysu w stosunkach międzynarodowych i stworzyć punkt wyjścia dla binarnego kodu kultury prawnej. Ten kod jest dla bezpieczeństwa prawnego tym, czym arystotelesowskie "nasienie dębu dla dębu (Brodecki, Nawrot 2007: 91). 
Ta trafna analiza dobrze oddaje sytuację cywilizacji. Umiejętność połączenia dwóch przeciwstawnych koncepcji filozoficznych wymaga wrażliwości, metodycznej pracy, a także wizjonerskiego spojrzenia. Internet stał się nową przestrzenią aktywności społecznej, która potrzebuje ponownej refleksji nad dotychczasowym funkcjonowaniem społeczeństwa. Zmiana technologiczna wymusza na nas ponowne skonstruowanie podstawowych pojęć społecznych, ponieważ społeczna przestrzeń funkcjonowania człowieka nabiera szerszego znaczenia, stając się bardziej płynna. Często konflikty wynikają z faktu, że prawo nie nadąża za zmieniającą się rzeczywistością. Prawo w swojej konstrukcji musi nabrać odpowiedniej dynamiki. Nie może funkcjonować tylko w hermetycznym środowisku profesjonalistów. W ten sposób stanie się semantycznym tworem zrozumiałym tylko dla kręgu wtajemniczonych. Wyzwaniem w dobie nowych mediów jest to, aby prawo nie tylko poznać, ale je stosować, tak aby stało się integralną częścią przestrzeni publicznej.

\section{Literatura:}

Anderson C., 2011, Za darmo: przyszłość najbardziej radykalnej z cen, tłum. M. Niemczuk-Kobosko, Kraków: Znak Litera Nova.

Brodecki Z., Nawrot A.M., 2007, Światynia w cyberkulturze: technologie cyfrowe i prawo w spoteczeństwie wiedzy, Gdańsk: Wydawnictwo Uniwersytetu Gdańskiego.

Druschel P., Backes M., Tirtea R., 2011, The right to be forgotten - between expectations and practice, http://www.enisa.europa.eu/activities/identity-and-trust/library/deliverables/ the-right-to-be-forgotten [dostęp: 23.11.2015].

Europa Praw Człowieka, 2012, Prawo do bycia zapomnianym - pytanie prejudycjalne, http://www. europapraw.org/news/prawo-do-bycia-zapomnianym-pytanie-prejudycjalne [dostęp: 23.11.2015].

Europa Praw Człowieka, 2013, Czy można znikną́ z Google? - komentarz do opinii rzecznika generalnego w sprawie C-131/12 Google przeciwko AEPD, http://www.europapraw.org/news/ czy-mozna-zniknac-z-google-komentarz-do-opinii-rzecznika-generalnego-w-sprawie-c-13112-google-przeciwko-aepd [dostęp: 23.11.2015].

European Commission, 2012a, Proposal for a DIRECTIVE OF THE EUROPEAN PARLIAMENT AND OF THE COUNCIL on the protection of individuals with regard to the processing of personal data by competent authorities for the purposes of prevention, investigation, detection or prosecution of criminal offences or the execution of criminal penalties, and the free movement of such data, http://ec.europa.eu/dgs/home-affairs/doc_centre/police/docs/com_2012_10_en.pdf [dostęp: 23.11.2015].

European Commission, 2012b, Proposal for a REGULATION OF THE EUROPEAN PARLIAMENT AND OF THE COUNCIL on the protection of individuals with regard to the processing of personal data and on the free movement of such data (General Data Protection Regulation), http://ec.europa.eu/justice/data-protection/document/review2012/com_2012_11_en.pdf [dostęp: 23.11.2015].

Hustinx P., 2012, Opinion of the European Data Protection Supervisor on the data protection reform package, https://secure.edps.europa.eu/EDPSWEB/webdav/shared/Documents/Consultation/Opinions/2012/12-03-07_EDPS_Reform_package_EN.pdf [dostęp: 23.11.2015].

Ilnicki M., 2014, Prawo do bycia zapomnianym w kontekście "postzniestawienia" informacji w sieci Internetu (cz.1), „Palestra” nr 1-2. 
Majczyna B., Szpunar M., 2012, Uwagi na piśmie Rzeczypospolitej Polskiej przedkładane na podstawie art. 23 Statutu Trybunału Sprawiedliwości w postępowaniu o wydanie orzeczenia wstępnego w sprawie C-131/12 Google Spain i Google (sad krajowy: Audiencia Nacional - Hiszpania), http://www.europapraw.org/files/2012/09/2012-06-28-C-131_12-uwagi-prejudycjalne. pdf [dostęp: 23.11.2015].

Moglen E, 2013, Wolność w chmurze i inne eseje, tłum. K. Makaruk et al., Warszawa: Fundacja Nowoczesna Polska.

Opinia rzecznika generalnego Nilia Jaasinena przedstawiona w dniu 25.06.2013, sprawa C-131/12, http://curia.europa.eu/juris/document/document.jsf?text $=\& d o c i d=138782 \&-$ pageIndex $=0 \&$ doclang $=P L \&$ mode $=$ req $\&$ dir $=\& o c c=$ first $\&$ part $=1 \&$ cid $=305413$ [dostęp: 23.11.2015].

Smętek J., Warso Z., 2012, "Prawo do bycia zapomnianym” - wzmocnienie autonomii informacyjnej, czy wprowadzenie cenzury w Internecie?, http://www.europapraw.org/files/2012/10/ Policy-paper_final_right-to-be-forgotten.pdf [dostęp: 23.11.2015].

Szymielewicz K., 2014, Niewidzialni sędziowie sieci, http://krytykapolityczna.pl/swiat/ue/ szymielewicz-niewidzialni-sedziowie-sieci/ [dostęp: 23.11.105].

Waglowski P., 2012, "Wyszukiwarki”, prawo do bycia zapomnianym, stanowisko RP w sprawie C-131/12, http://prawo.vagla.pl/node/9860 [dostęp: 23.11.2015].

Wang W., 2001, Internet, hakerzy, wirusy..., tłum. K. Gęstwa, Warszawa: RM.

Wniosek o wydanie orzeczenia w trybie prejudycjalnym złożony przez Audiencia Nacional (Hiszpania) w dniu 9 marca 2012 r. - Google Spain, S.L., Google, Inc. przeciwko Agencia de Protección de Datos (AEPD), Mario Costeja González (Sprawa C-131/12), http:// curia.europa.eu/juris/document/document.jsf?docid $=123131 \&$ doclang $=$ PL [dostęp: 23.11.2015].

\section{Abstrakt}

Internet stał się narzędziem przechowywania wspomnień. Jego dynamika i charakter spowodowały, że umieszczona w nim informacja zaczyna żyć, ewoluować. Upowszechnienie internetu umożliwiło szeroki dostęp do informacji, możliwość jej tworzenia czy modyfikacji. Kontrola nad informacją jest utrudniana, wręcz niemożliwa. Autonomia treści, jej ewolucja w niepozbawionej kontroli sieci może budzić obawy. Dlatego europejski prawodawca zmierza do uregulowania kwestii zarządzania informacją w internecie. Bezprecedensowy wyrok wydany przez Trybunał Sprawiedliwości daje prawo osobom prywatnym do bycia zapomnianym w sieci. W dobie nowych mediów wyrok ten staje się niejako drogowskazem określającym kierunek, w którym zmierza prawodawstwo.

\section{Słowa kluczowe}

prawo do bycia zapomnianym, informacja, internet, wyszukiwarka

\section{Summary}

\section{The Right to Be Forgotten - the Right in the Digital World}

The internet has become a tool for storing memories. The dynamics of the internet and its nature meant that the information begins to live, evolve. Access to information, the ability to create or modify the information has never been as high as at the time when the internet became widespread. Control of information is hindered, if not impossible. 
Autonomy content, not devoid of its evolution in network control may raise concerns. That is why the European legislator seeks to regulate the management of information on the internet. The unprecedented judgment of the Court of Justice gives individuals the right to be forgotten on the internet. In the era of new media, the judgment becomes kind of a beacon determining the direction in which the legislation seeks.

Keywords

right to be forgotten, information, internet, search 